University of Nebraska - Lincoln

DigitalCommons@University of Nebraska - Lincoln

USDA National Wildlife Research Center - Staff Publications
U.S. Department of Agriculture: Animal and Plant Health Inspection Service

2019

\title{
Experimental infections of Norway rats with avian-derived low-pathogenic influenza $A$ viruses
}

\author{
Kaci K. VanDalen \\ National Institute of Allergy and Infectious Diseases \\ Nicole M. Nemeth \\ University of Georgia \\ Nicholas 0. Thomas \\ Oregon State University \\ Nicole L. Barrett \\ USDA APHIS NWRC \\ Jeremy W. Ellis \\ USDA APHIS NWRC \\ Follow this and additional works at: https://digitalcommons.unl.edu/icwdm_usdanwrc \\ Part of the Natural Resources and Conservation Commons, Natural Resources Management and \\ Seficyextpage for additional a a thor'stal Sciences Commons, Other Veterinary Medicine Commons, \\ Population Biology Commons, Terrestrial and Aquatic Ecology Commons, Veterinary Infectious Diseases \\ Commons, Veterinary Microbiology and Immunobiology Commons, Veterinary Preventive Medicine, \\ Epidemiology, and Public Health Commons, and the Zoology Commons
}

VanDalen, Kaci K.; Nemeth, Nicole M.; Thomas, Nicholas O.; Barrett, Nicole L.; Ellis, Jeremy W.; Sullivan, Heather J.; Franklin, Alan B.; and Shriner, Susan A., "Experimental infections of Norway rats with avian-derived low-pathogenic influenza A viruses" (2019). USDA National Wildlife Research Center - Staff Publications. 2255.

https://digitalcommons.unl.edu/icwdm_usdanwrc/2255

This Article is brought to you for free and open access by the U.S. Department of Agriculture: Animal and Plant Health Inspection Service at DigitalCommons@University of Nebraska - Lincoln. It has been accepted for inclusion in USDA National Wildlife Research Center - Staff Publications by an authorized administrator of DigitalCommons@University of Nebraska - Lincoln. 


\section{Authors}

Kaci K. VanDalen, Nicole M. Nemeth, Nicholas O. Thomas, Nicole L. Barrett, Jeremy W. Ellis, Heather J. Sullivan, Alan B. Franklin, and Susan A. Shriner 


\title{
Experimental infections of Norway rats with avian-derived low-pathogenic influenza A viruses
}

\author{
Kaci K. VanDalen ${ }^{1,2} \cdot$ Nicole M. Nemeth $^{1,3} \cdot$ Nicholas O. Thomas $^{1,4} \cdot$ Nicole L. Barrett $^{1}$. Jeremy W. Ellis ${ }^{1}$. \\ Heather J. Sullivan ${ }^{1} \cdot$ Alan B. Franklin ${ }^{1} \cdot$ Susan A. Shriner ${ }^{1}$ (i)
}

Received: 24 February 2019 / Accepted: 28 February 2019 / Published online: 11 April 2019

(c) This is a U.S. government work and its text is not subject to copyright protection in the United States; however, its text may be subject to foreign copyright protection 2019

Influenza A viruses (IAVs) are a public-health, veterinary, and agricultural concern. Although wild birds are considered the primary reservoir hosts for most IAVs [36], wild-bird IAV strains are known to spill over into poultry, domestic or wild mammals, and humans [9, 17, 29, 34]. Occasionally, spillover events may result in adaptation or reassortment with other strains. Moreover, some IAV strains found in wild waterfowl mutate into highly pathogenic forms in poultry, causing tremendous economic losses [2]. When domestic animals, wildlife, and humans dwell in close proximity to each other, such as may be the case with agricultural operations, wildlife may represent a potential risk for interspecies pathogen transmission [5, 6, 10, 14, 17, 18, 26, 34]. Understanding the pathways through which IAV strains could spillover from waterfowl reservoirs into humans and domestic animals is important for limiting the spread of IAVs, as well as developing biosecurity and containment procedures in livestock and poultry production.

Experimental studies of common wild mammals in the U.S. [19-22, 26], bank voles (Myodes glareolus) in Europe and Asia [32], and black rats (Rattus rattus) in Japan [11] have shown varying degrees of IAV susceptibility and/or

Handling Editor: Ayato Takada.

Susan A. Shriner

Susan.A.Shriner@aphis.usda.gov

1 National Wildlife Research Center, United States Department of Agriculture/Animal and Plant Health Inspection Service, Fort Collins, CO 80521, USA

2 Present Address: National Institute of Allergy and Infectious Diseases, National Institutes of Health, Bethesda, MD 20892, USA

3 Present Address: Southeastern Cooperative Wildlife Disease Study, University of Georgia, Athens, GA 30602, USA

4 Present Address: Oregon State University/Oregon Health and Science University, Corvallis, OR, 97331, USA transmission in these synanthropic species. While Norway rats (Rattus norvegicus) are ubiquitous throughout rural and urban areas of the world and have the ability to range between these areas [23,27], only limited investigations of this species have been conducted $[1,24,25,38]$, and their role in IAV transmission has not been clearly established. The main objective of this study was to further characterize IAV infection in Norway rats using IAV strains derived from poultry and wild water birds.

Norway rats were purchased from two local commercial sources (Animal Attraction, Greeley, CO, USA, and Scales ' $n$ Tails, Northglenn, CO, USA) and transported to the USDA-APHIS-WS National Wildlife Research Center (NWRC), Fort Collins, CO. The Institutional Animal Care and Use Committee at the NWRC approved all experimental procedures and animal holding conditions prior to and during experimentation (approval no. QA-1620). Animals were group-housed as same-sex cohorts of three with the recommended environmental conditions outlined by the National Research Council [7]. Prior to experimental inoculations, blood samples were collected from each rat to screen for antibodies to IAV using an epitope-blocking enzyme-linked immunosorbent assay (bELISA, [30]), and all animals were confirmed to be seronegative.

One hundred five rats were randomly divided among five treatment groups representing inoculations with one of four viral strains or negative controls. Two of the IAV strains used in the inoculations were derived from chickens, one was collected as part of United States wild-bird surveillance [8] and then passaged through a mallard, and the fourth was collected from the wild-bird surveillance. Each of the viruses was propagated in specific-pathogen free (SPF) chicken eggs prior to experimental infections. Detailed information on these viruses is provided in reference 26 .

Twenty-four rats each were inoculated with one of four IAV virus strains: A/CK/CA/S0408793/04(H6N2) [37], A/CK/AL/75(H4N8) [3, 4, 12], A/mallard/CO/ 
P66F1-5/08(H4N6) [35], or A/wildbird/CA/18771826/08(H3N8) [33]. These virus subtypes were selected because they represent two of the most common subtypes in wild birds in North America $[13,15]$ and have been associated with outbreaks, both in commercial poultry and in a live-bird market $[12,37]$. Nine rats were mock inoculated with negative amnio-allantoic fluid (AAF). Each treatment group was kept in a separate animal biosafety level 2 (BSL2) room to prevent cross-contamination. After isoflurane inhalation anesthesia, rats were inoculated intranasally with approximately $10^{5} \mathrm{EID}_{50}$ of virus delivered in $100 \mu \mathrm{L}$ of AAF or with $100 \mu \mathrm{L}$ of negative AAF by dispensing $50 \mu \mathrm{L}$ of inoculum into each nostril.

Three rats from each virus treatment group were euthanized per day on days 1-7 post-inoculation and then again on day 14 . Three negative-control rats were euthanized and sampled on each of days 6,7 , and 14 post-inoculation. Rats were euthanized via carbon dioxide intoxication after anesthesia by isoflurane inhalation. Samples were collected from oral, nasal, and fecal swabs; respiratory tissues from nasal turbinates, tracheas, and cranial and caudal lobes of the lungs; and serum samples. Samples were collected immediately after euthanasia and were stored at $-80^{\circ} \mathrm{C}$ until laboratory testing. All samples were homogenized in TRIzol Reagent prior to testing and were then assayed for the presence of IAV RNA by real-time quantitative reverse transcription polymerase chain reaction (qRT-PCR). Viral RNA was extracted from samples using a MagMAX-96 AI/ND Viral RNA Isolation Kit, and qRT-PCR was performed using primers and probes developed by Spackman et al. [28]. The extraction methods are described in detail by Shriner et al. [26] and the qRT-PCR methods are described by Van Dalen et al. [35]. Calibrated controls with known viral titers $\left(10^{2}\right.$ $\mathrm{EID}_{50} / \mathrm{mL}-10^{5} \mathrm{EID}_{50} / \mathrm{mL}$ ) were analyzed on each qRT-PCR plate to construct 4-point standard curves. The amount of viral RNA in the samples was extrapolated from the standard curves and expressed as PCR EID $_{50}$ equivalents $/ \mathrm{mL}$. Selected tissue samples were also tested by virus isolation in SPF embryonated chicken eggs following standard protocols [31] to confirm the presence of infectious virus.

In order to compare infection characteristics, we compared viral replication across viral subtypes (H3N8, H4N6, H4N8, and H6N2), tissue types (caudal lung, cranial lung, nasal turbinates, and trachea), and host sex (male and female) using multivariate linear regression. Prior to statistical analysis, all tissues were standardized by weight. We compared all possible model variable combinations of subtype, tissue type, sex, days post-inoculation, and all two-way and three-way interactions between subtype, tissue type, and sex using Akaike's information criterion (AIC) corrected for small sample sizes (AICc, Table 1). All statistical analyses were conducted in $\mathrm{R}$ version 3.4.0 [16]

All control rats remained negative for IAV RNA throughout the study. For the inoculated rats, the rate of viral RNA replication varied by strain and was detected in multiple respiratory tissues across multiple days post-infection, suggesting that these IAV strains were able to replicate in Norway rats. In general, the amount of viral RNA detected in tissue samples was extremely low for the H4N8 virus, minimal for the H6N2 virus, and moderate for the H3N8

Table 1 Model selection results for regression models testing the relationship between viral RNA concentration as a function of virus subtype, tissue sex, and day post-inoculation (DPI) and two-way interactions between the variables

\begin{tabular}{|c|c|c|c|c|c|}
\hline Model & Adj. $\mathrm{R}^{2}$ & $\mathrm{~K}$ & $\mathrm{AICc}$ & delta AICc & AICc weight \\
\hline Subtype + Tissue + Sex + DPI + Subtype*DPI & 0.34 & 13 & 963.55 & 0.00 & 0.33 \\
\hline Subtype + Tissue + Sex + DPI + Subtype*DPI + Subtype*Sex & 0.34 & 16 & 964.50 & 0.96 & 0.20 \\
\hline Subtype + Tissue + Sex + DPI + Subtype $*$ DPI + Tissue $*$ Sex & 0.34 & 16 & 966.20 & 2.65 & 0.09 \\
\hline Subtype + Tissue + Sex + DPI + Subtype*DPI + Subtype*Sex + Tissue*DPI & 0.35 & 19 & 966.61 & 3.06 & 0.07 \\
\hline Subtype + Tissue + Sex + DPI + Subtype $*$ DPI + Subtype*Tissue & 0.37 & 22 & 966.63 & 3.08 & 0.07 \\
\hline Subtype + Tissue + Sex + DPI + Subtype $*$ Sex + Subtype*DPI + Tissue $*$ Sex & 0.34 & 19 & 967.15 & 3.61 & 0.05 \\
\hline Subtype + Tissue + Sex + DPI + Subtype*DPI + Subtype $*$ Tissue + Tissue ${ }^{*}$ Sex & 0.36 & 25 & 967.46 & 3.91 & 0.05 \\
\hline Subtype + Tissue + Sex + DPI + Subtype $*$ DPI + Subtype $*$ Tissue + Subtype $*$ Sex & 0.37 & 25 & 967.59 & 4.05 & 0.04 \\
\hline $\begin{array}{l}\text { Subtype }+ \text { Tissue }+ \text { Sex }+ \text { DPI }+ \text { Subtype*DPI }+ \text { Subtype*Tissue }+ \text { Subtype*Sex }+ \\
\text { Tissue*Sex }\end{array}$ & 0.37 & 28 & 968.38 & 4.84 & 0.03 \\
\hline Subtype + Tissue + Sex + DPI + Subtype*DPI + Subtype*Tissue + Tissue*DPI & 0.37 & 25 & 968.75 & 5.21 & 0.02 \\
\hline $\begin{array}{l}\text { Subtype + Tissue }+ \text { Sex }+ \text { DPI }+ \text { Subtype*DPI }+ \text { Subtype*Tissue }+ \text { Subtype*Sex }+ \\
\text { Tissue*DPI }\end{array}$ & 0.38 & 25 & 968.81 & 5.26 & 0.02 \\
\hline Subtype + Tissue + Sex + DPI + Subtype*DPI + Tissue $*$ Sex + Tissue*DPI & 0.34 & 19 & 969.11 & 5.57 & 0.02 \\
\hline
\end{tabular}

Only models with a $\Delta$ AICc $<6$ are shown. $\mathrm{K}$ is the number of parameters. Adj. $\mathrm{R}^{2}$ is the $\mathrm{R}^{2}$ value adjusted for the number of parameters in the model; it indicates the amount of variation explained by the model. AICc is Akaike's information criterion adjusted for small sample size. $\triangle \mathrm{AICc}$ values indicate the difference between a given model and the best model (the model with the lowest AICc score). The AIC weight shows the relative support for each model 
and H4N6 viruses. The amount of viral RNA as monitored by fecal, oral, and nasal swabs was minimal for each of the IAV strains studied. No IAV RNA was detected in fecal or oral swabs, and only 12 of the 94 nasal swabs collected from inoculated rats were positive for viral RNA $(\mathrm{H} 4 \mathrm{~N} 8=0$, $\mathrm{H} 6 \mathrm{~N} 2=3, \mathrm{H} 4 \mathrm{~N} 6=4, \mathrm{H} 3 \mathrm{~N} 8=5$ ) with five of the 12 positives identified at 1 day-post inoculation (DPI). The mean quantity of viral RNA detected in the nasal swabs for the different strains was relatively low $\left(\leq 3.32 \log _{10}\right.$ PCR EID $_{50}$ equivalents $/ \mathrm{mL}$ ). Only two of the 12 rats tested at 14 DPI were seropositive for antibodies to IAV (one inoculated with the $\mathrm{H} 3 \mathrm{~N} 8$ virus and one inoculated with the H4N6 virus), but this result was expected, since we did not retain the rats for an additional week when antibodies were more likely to be detected.

The only positive samples from the 23 rats inoculated with the H4N8 virus were from six nasal turbinate samples. Three samples were positive at 1 DPI, with one positive each on days 2, 4, and 5 post-inoculation. All viral RNA quantities varied between 1.00 and $1.70 \log _{10}$ PCR EID 50 equivalents/mL (Fig. 1).

For the 23 rats inoculated with the H6N2 virus, viral RNA was detected in nasal turbinates, cranial lung tissue, and caudal lung tissue, with no viral RNA detected in trachea. Viral RNA loads were highest in nasal turbinates $(\mathrm{n}=$ 6 rats), with a peak viral load of $3.5 \log _{10}$ PCR EID 50 equivalents $/ \mathrm{mL}$. RNA was also detected in cranial lung sections (n $=6$, peak viral load of $2.89 \log _{10}$ PCR EID 50 equivalents/ $\mathrm{mL}$ ) and in the caudal lung sections of two rats (peak viral load of $2.07 \log _{10}$ PCR EID 50 equivalents $/ \mathrm{mL}$ ).

IAV RNA was detected in all four tissue types tested from the 24 rats inoculated with H4N6. Similar to rats inoculated with other strains, IAV RNA was most often detected in nasal turbinates $(n=14)$, with a peak viral load of $4.78 \log _{10}$ PCR EID $_{50}$ equivalents/mL. Of these 14 rats, six also had IAV RNA detected in cranial lung sections (peak viral load
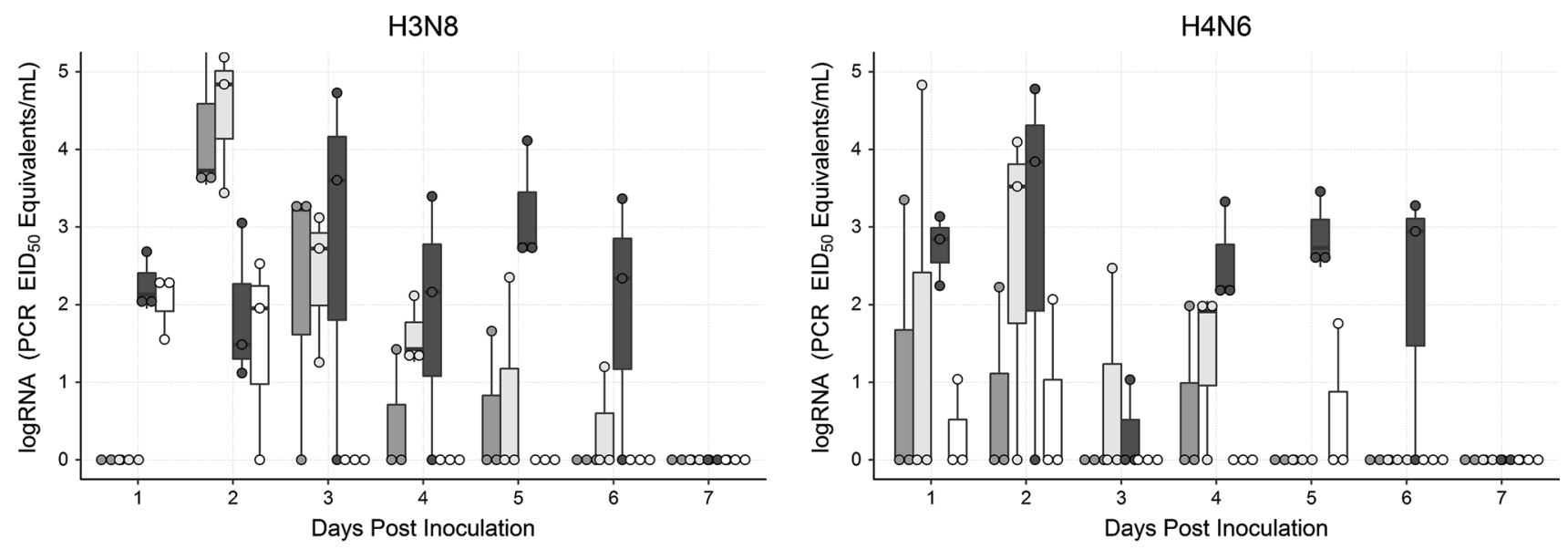

H4N8
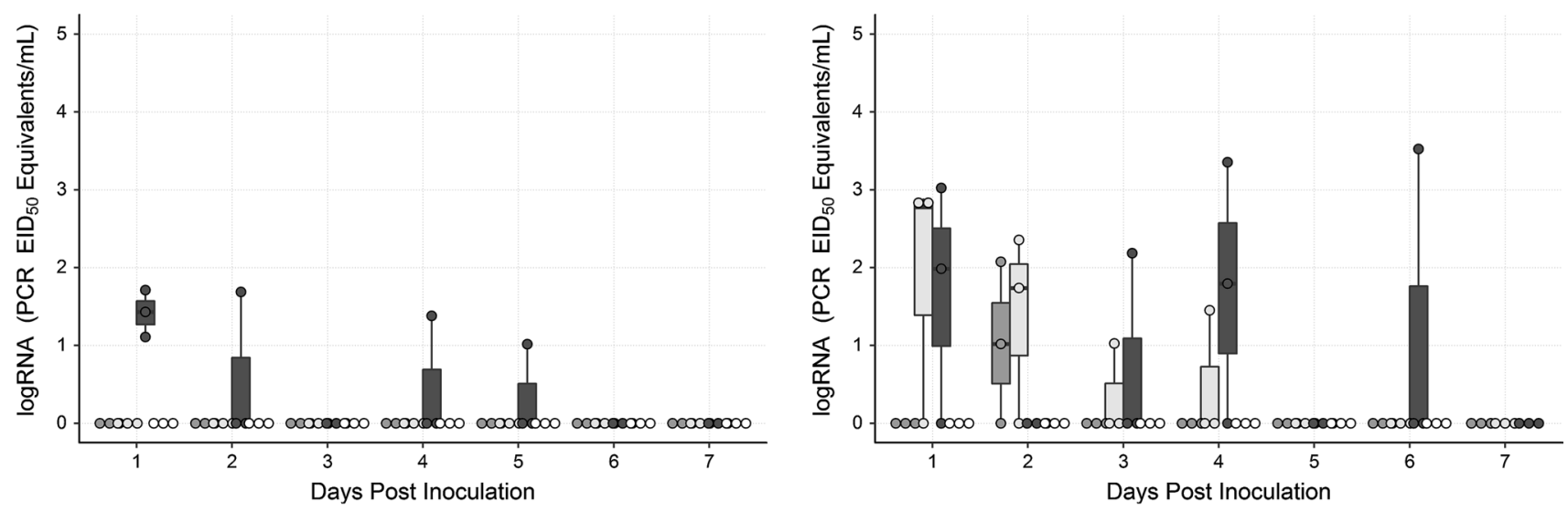

TISSUE TYPE 官 Caudal Lung 追 Cranial Lung Nasal Turbinates

Fig. 1 Influenza A viral RNA detection for four respiratory tissues collected from Norway rats inoculated with avian-derived influenza A viruses. The H3N8 and H4N6 viruses were originally collected from wild birds and the H4N8 and H6N2 viruses were originally collected from poultry. Three rats were sampled perday 
of $4.09 \log _{10}$ PCR EID E0 $_{5}$ equivalents/mL), three rats had IAV RNA detected in caudal lung sections (peak viral load of $3.35 \log _{10}$ PCR equivalent $E_{50} / \mathrm{mL}$ ), and three rats had IAV RNA detected in trachea samples (peak viral load of $2.06 \log _{10}$ PCR equivalent $\mathrm{EID}_{50} / \mathrm{mL}$ ).

Finally, of the 24 rats inoculated with H3N8, 18 individuals had evidence of IAV RNA in tissues. IAV RNA was detected in nasal turbinates of 15 rats (peak viral load of 4.73 $\log _{10}$ PCR EID S0 $_{0}$ equivalents/mL), caudal lung sections of seven rats (peak viral load of $5.45 \log _{10}$ PCR EID F0 $_{50}$ equivalents $/ \mathrm{mL}$ ) and cranial lung sections of 11 rats (peak viral load of $5.19 \log _{10}$ PCR PCR EID 50 equivalents $/ \mathrm{mL}$ ). Lower quantities of IAV RNA were also detected in the trachea of five individuals (peak viral load of $2.52 \log _{10}$ PCR EID $_{50}$ equivalents $/ \mathrm{mL}$ ).

While we found the highest RNA viral loads in nasal turbinate tissues, the amount of sample remaining after qRTPCR testing was insufficient for virus isolation. However, we did have adequate tissue available to test four lung samples (two H3N8 and two H4N6) with RNA viral loads suitable for virus isolation. All four samples were positive for infectious virus.

The model-selection results for the regression models testing associations between viral RNA concentrations and viral subtype, tissue type, host sex, DPI, and interactions between these variables showed that the best model by AICc included subtype, tissue, sex, DPI, and an interaction between subtype and DPI (Table 1). This model had an AICc weight of 0.33 , indicating that there is a $33 \%$ chance that this model best explains the collected data. All of the models with AICc support included the variables in the top model but also included 1-3 additional interaction variables. The regression coefficients and ANOVA results for the top model (Table 2) show that all of the variables in the top model are statistically significant, indicating that the quantity of viral RNA detected varied by subtype, tissue, sex, and DPI. In general, viral RNA excretion was highest for the H4N6 virus and nasal turbinate tissues. RNA quantities were also slightly higher in females than in males and RNA quantities decreased as DPI increased.

Our results suggest that Norway rats can be infected with multiple strains of IAV, but the efficiency of replication is strain dependent, and only limited shedding of the virus can be measured in fecal, oral, or nasal swabs. On the other hand, moderate levels of replication were observed in respiratory tissues. Interestingly, the two poultry viruses that we tested, H4N8 and H6N2, exhibited significantly lower rates of viral RNA replication when compared with the two wild-bird-origin viruses, H3N8 and H4N6, which replicated without adaptation. Testing of additional virus strains is needed to elucidate whether this difference is associated with general strain and subtype variability or with the origin of these strains in poultry or wild birds. Testing of isolates of the same subtype from both wild birds and poultry could provide further information about the relationship of the origin of the virus to its ability to replicate in rats. One prospect for future study is additional H6N2 testing, since this subtype is common in both wild
Table 2 Regression coefficients and ANOVA table for the best model as selected by Akaike's information criteria (AIC)

\begin{tabular}{|c|c|c|c|c|c|}
\hline Variable & & Parameter estimate & Std. error & $t$-value & $\operatorname{Pr}(>|t|)$ \\
\hline (Intercept) & & 2.379 & 0.272 & 8.751 & $<0.001$ \\
\hline Subtype H4N6 & & -0.863 & 0.352 & -2.454 & 0.002 \\
\hline Subtype H4N8 & & -2.341 & 0.354 & -6.621 & $<0.001$ \\
\hline Subtype H6N2 & & -1.635 & 0.351 & -4.655 & $<0.001$ \\
\hline Tissue cranial lung & & 0.322 & 0.155 & 2.075 & 0.0388 \\
\hline Tissue nasal turbinates & & 0.872 & 0.155 & 5.620 & $<0.001$ \\
\hline Tissue trachea & & -0.230 & 0.157 & -1.466 & 0.014 \\
\hline Sex male & & -0.224 & 0.118 & -1.891 & 0.060 \\
\hline DPI & & -0.323 & 0.055 & -5.87 & $<0.001$ \\
\hline Subtype H4N6:DPI & & 0.124 & 0.079 & 1.568 & 0.118 \\
\hline Subtype H4N8:DPI & & 0.294 & 0.079 & 3.741 & 0.001 \\
\hline Subtype H6N2:DPI & & 0.196 & 0.080 & 2.447 & 0.015 \\
\hline Variable & Df & Sum Sq & Mean Sq & F-value & $\operatorname{Pr}(>F)$ \\
\hline Subtype & 3 & 63.100 & 21.030 & 20.790 & $<0.001$ \\
\hline Tissue & 3 & 55.460 & 18.490 & 18.274 & $<0.001$ \\
\hline Sex & 1 & 6.910 & 6.909 & 6.830 & 0.009 \\
\hline DPI & 1 & 38.100 & 38.100 & 37.666 & $<0.001$ \\
\hline Subtype:DPI & 3 & 15.060 & 5.021 & 4.963 & 0.002 \\
\hline
\end{tabular}

DPI is days post-inoculation. Subtype comparisons are to subtype H3N8, tissue comparisons are to caudal lung, and subtype:DPI comparisons are to subtype H3N8 
birds and outbreaks in live-bird markets. Other possibilities worth investigating are receptor characterization in Norway rat tissues and molecular adaptations associated with replication in this species. A difference between the wild-bird and poultry viruses that should be noted is their differing passage histories. Both of the poultry viruses were laboratory adapted, as they had been passaged in eggs many times, while the two wild-bird viruses were first passages.

We detected little to no IAV shedding in oral swabs or feces, but we did detect moderate quantities of IAV RNA in nasal secretions $\left(\leq 3.32 \log _{10}\right.$ PCR EID Ev $_{50}$ equivalents/ $\mathrm{mL}$ ) and upper respiratory tissues. These results are similar to those obtained with wild house mice infected with multiple IAVs where nasal shedding of viral RNA was moderate (mean $\leq 4.49 \log _{10}$ PCR EID $_{50}$ equivalents $/ \mathrm{mL}$ ) but oral shedding and fecal shedding was minimal or undetectable [26]. Likewise, oropharyngeal swabs of SpragueDawley rats inoculated with $\mathrm{H} 7 \mathrm{~N} 3$ or $\mathrm{H} 5 \mathrm{~N} 2$ viruses were all negative, although $80-100 \%$ of inoculated rats developed antibodies to IAV [1]. These results differ from those obtained with other common mammals, such as striped skunks and cottontails inoculated with H4N6, which shed greater quantities of IAV RNA orally and nasally (maximum concentrations were between 5.09 and $6.94 \log _{10}$ PCR equivalent $\mathrm{EID}_{50} / \mathrm{mL}$ ) [20, 21], and may differ from those obtained with rodents experimentally infected with highly pathogenic avian influenza (HPAI) strains [24, 32].

While shedding of viral RNA in Norway rats was minimal to moderate for all of the virus strains tested, these results demonstrate that IAV RNA can be detected in respiratory tract tissues at higher quantities than in oral or nasal swabs. Preventing the potential spread of IAV from reservoir waterfowl to humans, domestic animals, and livestock requires an understanding of viral transmission in human-occupied areas and agricultural operations. The higher levels of IAV RNA detected in respiratory tissues of Norway rats (versus external shedding) suggests that the main risk of IAV transmission from rats would be due to consumption of infected respiratory tissues by predators and/or scavengers. Many domesticated animals, such as swine, barnyard chickens, dogs, and cats prey on or scavenge infected Norway rats, and humans may be at risk when handling infected carcasses. While Norway rats are not likely to play a large role in IAV transmission, infection may be strain dependent, and further investigation of the infection dynamics of additional strains and other small mammals will aid in directing risk mitigation, biosafety practices, and rodent control on farms and in urban areas.
Acknowledgements We appreciate the generous donation of virus from the Southeast Poultry Research Laboratory. Thanks also to Daniel N. Gossett and the National Wildlife Research Center Animal Care Staff for animal husbandry, and Gordon R. Gathright for veterinary support.

\section{References}

1. Achenbach JE, Bowen RA (2011) Transmission of avian influenza A viruses among species in an artificial barnyard. PLoS One 6:e17643

2. Alexander DJ (2000) A review of avian influenza in different bird species. Vet Microbiol 74:3-13

3. Brugh M, Beard CW (1986) Influence of dietary calcium stress on lethality of avian influenza viruses for laying chickens. Avian Dis 30:672-678

4. Brugh M (1992) Re-evaluation of the pathogenicity of A/ chicken/Alabama/75 (H4N8) influenza virus. Avian Dis 36:968-974

5. Cardona CJ (2005) Low-pathogenicity avian influenza A outbreaks in commercial poultry in California. In: Knobler SL, Mack A, Mahmoud A, Lemon SM (eds) The threat of pandemic influenza: are we ready?. National Academies Press, Washington, D. C., pp 243-253

6. Clark L, Hall J (2006) Avian influenza in wild birds: status as reservoirs, and risks to humans and agriculture. Ornithol Monogr 60:3-29

7. Council NR (2011) Guide for the care and use of laboratory animals, 8th edn. National Academies Press, Washington, D.C.

8. Deliberto TJ, Swafford SR, Nolte DL, Pedersen K, Lutman MW, Schmit BB, Baroch JA, Kohler DJ, Franklin A (2009) Surveillance for highly pathogenic avian influenza in wild birds in the USA. Integr Zool 4:426-439

9. Gao R, Cao B, Hu Y, Feng Z, Wang D, Hu W, Chen J, Jie Z, Qiu H, Xu K, Xu X, Lu H, Zhu W, Gao Z, Xiang N, Shen Y, He Z, Gu Y, Zhang Z, Yang Y, Zhao X, Zhou L, Li X, Zou S, Zhang Y, Li X, Yang L, Guo J, Dong J, Li Q, Dong L, Zhu Y, Bai T, Wang S, Hao P, Yang W, Zhang Y, Han J, Yu H, Li D, Gao GF, Wu G, Wang Y, Yuan Z, Shu Y (2013) Human infection with a novel avian-origin influenza A (H7N9) virus. N Engl J Med 368:1888-1897

10. Grear DA, Dusek RJ, Walsh DP, Hall JS (2017) No evidence of infection or exposure to highly pathogenic avian influenzas in peridomestic wildlife on an affected poultry facility. J Wildl Dis 53:37-45

11. Hiono T, Okamatsu M, Yamamoto N, Ogasawara K, Endo M, Kuribayashi S, Shichinohe S, Motohashi Y, Chu DH, Suzuki M, Ichikawa T, Nishi T, Abe Y, Matsuno K, Tanaka K, Tanigawa T, Kida H, Sakoda Y (2016) Experimental infection of highly and low pathogenic avian influenza viruses to chickens, ducks, tree sparrows, jungle crows, and black rats for the evaluation of their roles in virus transmission. Vet Microbiol 182:108-115

12. Johnson DC, Burton GM, Moulthrop JI (1977) Epidemiologic studies of the 1975 avian influenza outbreak in chickens in Alabama. Avian Dis 21:167-177

13. Krauss S, Walker D, Pryor SP, Niles L, Chenghong L, Hinshaw VS, Webster RG (2004) Influenza A viruses of migrating wild aquatic birds in North America. Vector-Borne Zoonotic Dis 4:177-189

14. McQuiston JH, Garber LP, Porter-Spalding BA, Hahn JW, Pierson FW, Wainwright SH, Senne DA, Brignole TJ, Akey BL, Holt TJ (2005) Evaluation of risk factors for the spread of low pathogenicity H7N2 avian influenza virus among commercial poultry farms. J Am Vet Med Assoc 226:767-772 
15. Piaggio AJ, Shriner SA, VanDalen KK, Franklin AB, Anderson TD, Kolokotronis SO (2012) Molecular surveillance of low pathogenic avian influenza viruses in wild birds across the United States: inferences from the hemagglutinin gene. PLoS One 7(12):e50834

16. Development Core Team R (2010) R: a language and environment for statistical computing. R Foundation for Statistical Computing, Vienna

17. Reperant LA, Rimmelzwaan GF, Kuiken T (2009) Avian influenza viruses in mammals. OIE Revue Scientifique et Technique 28:137-159

18. Roberts NM, Henzler DJ, Clark L (2009) Serologic evidence of avian influenza (H4N6) exposure in a wild-caught raccoon. Avian Dis 53:455-457

19. Root JJ, Bentler KT, Shriner SA, Mooers NL, VanDalen KK, Sullivan HJ, Franklin AB (2014) Ecological routes of avian influenza virus transmission to a common mesopredator: an experimental evaluation of alternatives. PLoS One 9:e102964

20. Root JJ, Shriner SA, Bentler KT, Gidlewski T, Mooers NL, Ellis JW, Spraker TR, VanDalen KK, Sullivan HJ, Franklin AB (2014) Extended viral shedding of a low pathogenic avian influenza virus by striped skunks (Mephitis mephitis). PLoS One 9:e70639

21. Root JJ, Shriner SA, Bentler KT, Gidlewski T, Mooers NL, Spraker TR, VanDalen KK, Sullivan HJ, Franklin AB (2014) Shedding of a low pathogenic avian influenza virus in a common synanthropic mammal-the cottontail rabbit. PLoS One 9:e102513

22. Root JJ, Shriner SA, Ellis JW, VanDalen KK, Sullivan HJ, Franklin AB (2015) When fur and feather occur together: interclass transmission of avian influenza A virus from mammals to birds through common resources. Sci Rep 5:14354

23. Russell JC, Towns DR, Anderson SH, Clout MN (2005) Intercepting the first rat ashore. Nature 437:1107

24. Shortridge KF, Zhou NN, Guan Y, Gao P, Ito T, Kawaoka Y, Kodihalli S, Krauss S, Markwell D, Murti KG (1998) Characterization of avian $\mathrm{H} 5 \mathrm{~N} 1$ influenza viruses from poultry in Hong Kong. Virology 252:331-342

25. Shortridge KF, Gao P, Guan Y, Ito T, Kawaoka Y, Markwell D, Takada A, Webster RG (2000) Interspecies transmission of influenza viruses: H5N1 virus and a Hong Kong SAR perspective. Vet Microbiol 74:141-147

26. Shriner SA, VanDalen KK, Mooers NL, Ellis JW, Sullivan HJ, Root JJ, Pelzel AM, Franklin AB (2012) Low-pathogenic avian influenza viruses in wild house mice. PLoS One 7:e39206

27. Singleton GR, Hinds LA, Leirs H, Zhang Z (1999) Ecologicallybased management of rodent pests. ACIAR Monogr 59:494
28. Spackman E, Ip HS, Suarez DL, Slemons RD, Stallknecht DE (2008) Analytical validation of a real-time reverse transcription polymerase chain reaction test for Pan-American lineage H7 subtype Avian influenza viruses. J Vet Diagn Investig 20:612-616

29. Subbarao K, Katz J (2000) Avian influenza viruses infecting humans. Cell Mol Life Sci 57:1770-1784

30. Sullivan HJ, Blitvich BJ, VanDalen K, Bentler KT, Franklin AB, Root JJ (2009) Evaluation of an epitope-blocking enzyme-linked immunosorbent assay for the detection of antibodies to influenza A virus in domestic and wild avian and mammalian species. $\mathbf{J}$ Virol Methods 161:141-146

31. Szretter KJ, Balish AL, Katz JM (2006) Influenza: propagation, quantification, and storage. Wiley, Hoboken

32. Tejeda AR, Aiello R, Salomoni A, Berton V, Vascellari M, Cattoli G (2015) Susceptibility to and transmission of H5N1 and H7N1 highly pathogenic avian influenza viruses in bank voles (Myodes glareolus). Vet Res 46:51

33. U.S. Interagency Working Group (2006) An early detection system for highly pathogenic $\mathrm{H} 5 \mathrm{~N} 1$ avian influenza in wild migratory birds: U.S. Interagency Strategic Plan. U.S. Interagency Working Group, Washington, D.C.

34. VanDalen KK, Shriner SA, Sullivan HJ, Root JJ, Franklin AB (2009) Monitoring exposure to avian influenza viruses in wild mammals. Mammal Rev 39:167-177

35. VanDalen KK, Franklin AB, Mooers NL, Sullivan HJ, Shriner SA (2010) Shedding light on avian influenza H4N6 infection in mallards: modes of transmission and implications for surveillance. PLoS One 5:e12851

36. Webster RG, Bean WJ, Gorman OT, Chambers TM, Kawaoka Y (1992) Evolution and ecology of influenza A viruses. Microbiol Rev 56:152-179

37. Yee KS, Carpenter TE, Farver TB, Cardona CJ (2009) An evaluation of transmission routes for low pathogenicity avian influenza virus among chickens sold in live bird markets. Virology 394:19-27

38. Cummings CO, Hill NJ, Puryear WB, Rogers B, Mukherjee J, Leibler JH, Rosenbaum MH, Runstadler JA (2019) Evidence of Influenza A in Wild Norway Rats (Rattus norvegicus) in Boston, Massachusetts. Front Ecol Evol. https://doi.org/10.3389/ fevo.2019.00036

Publisher's Note Springer Nature remains neutral with regard to jurisdictional claims in published maps and institutional affiliations. 